\title{
Trust and Confidence: History, Theory and Socio-Political Implications
}

\author{
Christian Morgner
}

Published online: 10 July 2013

(C) Springer Science+Business Media Dordrecht 2013

\begin{abstract}
Even before trust became a buzzword, theoretical developments were made, which have instigated the development of two forms of trust which are described as personal trust and system trust/confidence. However, this distinction remained rather secondary in the overall literature. There is an overall lack on the historical developments of these forms of trust, their internal logic and how they interlink, overlap, or work against each other. The paper aims to advance these three aspects: first through a historical overview of the semantic of this distinction, followed by a theoretical reconstruction of the historical material and third by demonstrating how these theoretical concepts can be applied to political crises (Revolutions of 1989), thus revealing their logic and mutual interlocking.
\end{abstract}

Keywords Political sociology · Trust - History · Political crises - System trust · Social theory

\section{Introduction}

The role of trust and its related consequences (societal relations, cooperation) is judged by many as significant within modern society (Giddens 1990: 34). Trustfavourably described as a social commodity—is entwined with the uncertainties,

Dr. Christian Morgner is lecturer in sociology at University of Lucerne $(\mathrm{CH})$. He held visiting scholarships and positions at various universities, including the University of Cambridge, Sotheby's Institute London, Yale University, and EHESS, Paris. He has published on issues of global communication, sociological, theory, political sociology, and culture/arts. He currently works on a project about the globalisation of the arts and on political interactions.

C. Morgner $(\bowtie)$

Department of Sociology, University of Lucerne, Frohburgstrasse 3, Postbox 4466, 6002 Lucerne, Switzerland e-mail: christian.morgner@unilu.ch 
ambiguities and contingencies produced by modern society: "[t]he importance of trust pervades the most diverse situations where cooperation is at one and the same time a vital and fragile commodity: from marriage to economic development, from buying a second-hand car to international affairs, from the minutiae of social life to the continuation of life on earth" (Gambetta 1988b: II). This broad range of social activities has surely contributed to the boom in scientific literature since the late 1990s (see Ebert 2007 and for overviews see Arnott 2007; Bachmann and Zaheer 2006, 2008). Four areas have received special attention, namely political and economic affairs, organisations, and the internet. These studies tackle a vast range of issues, such as online shopping/internet (Jarvenpaa et al. 2002; Lee and Turban 2001; Suh and Han 2002), trading and management (Chua et al. 2008; Bradford et al. 2009), affiliations between organisations (Bachmann and Lane 1998), social capital and politics (Uslaner 2002, 2008; Newton 2011), voting (Levi 2000), and rational choice theory (Hardin 2002). This brief overview, which is far from being complete, demonstrates that trust is a topic of intense research. Nevertheless, even before trust became a buzzword, theoretical developments were made, which have instigated the development of two forms of trust which are described as personal trust and system trust/confidence in post-modern society. ${ }^{1}$ Whilst personal trust represents a micro concern, system trust/confidence represents a macro concern. The corresponding literature has rather focused on the different levels of trust with regard to personal encounters, such as in economic research or focusing on organisations or large-scale historical examples or speaking of trust in relation to other abstract concepts (see the aforementioned studies). This division has caused the categorisation of trust into two different forms to remain neglected or to just be an analytical distinction and the mutuality between the two forms of trust has not been empirically examined or further theorised (see Smith 2005). Instead of approaching trust from a perspective of dealing with small social versus big social phenomena, this paper will focus on the inherent structure, meaning, and logic of the two types. Thus, this paper will argue that the distinction of trust/confidence is not simply due to the social size they are dealing with, but that they co-develop in relationship to the inherent logic of the social structures they enable and through which they are enabled. For example, when forms of confidence emerge, the use of money as a token can spread and with its general implementation and reliability, confidence can be imported into other areas. Trust is then not a psychological or genetic condition but a medium of social order. Trust thus varies in relation to the structure of society and vice versa. Consequently, the first step would be to prove this changing and adapting quality. Emphasis will placed on the semantic side and how these developments contribute to the formation of trust and confidence in contemporary society. Thus, less attention will be placed on the more sociostructural aspects of the historical societies that are discussed. Furthermore, such a historical foray should demonstrate that the distinction is itself a result of modernity. The purpose is to elucidate in this way the general framework of the theoretical concepts of trust, and to investigate how semantic meanings develop, which are then

\footnotetext{
1 The main authors using this distinction are Niklas Luhmann, James Coleman, and Anthony Giddens (see Offe 1999: 44ff.). This distinction derives from the writings of Simmel (2004) and Luhmann (1979).
} 
used in the further linguistic and definitive evolution of the meaning of trust, and eventually how they become stabilised within the distinctions between personal and system trust. With this distinction emerging in contemporary society, the paper will identify in theoretical terms how this distinction is embedded in those social circumstances, like the division of society into different social spheres, the development of organisations, and the role of everyday interactions. Upon this base and through the use of theory, the distinction between the two forms of trust will be exemplified. This historical foray had to demonstrate the meaning or development of this medium of social order and this part aims to elaborate on the inherent structure of trust with regard to contemporary society. ${ }^{2}$ This chapter remains relatively abstract and focuses on rather general theoretical categories. Therefore, the last part of the essay will apply the developed terms to two case studies, which deal with the crises of trust/confidence (see Endreß 2010). In doing so, it will illustrate the interplay and functioning of personal and system trust during the Watergate scandal and the changes in Eastern Europe around 1989. Consequently, this part will pay closer attention to the co-evolution of the semantics of trust in contemporary society and its underlying structure. The following questions will be raised in this context: can personal trust lead to the building of system trust and vice versa? Why does personal trust have a deeper binding effect, yet at the same time, is more frequently dissolved? Does system trust enable such a change, and why is system trust typically viewed as less intense, when it is also more stable?

\section{The Semantics of Personal and System Trust}

The semantics of trust have a long, evolutionary history. In ancient Greece its antecedents were represented by the words pistis and apista; in the Roman Empire 'trust' was represented by fides/fiducia and the opponent's sollicitudo/fraus/perfial infamia. The Christian Middle Ages distinguished fides and fiducia more exactly, and had their opponents in timor (fear) and insecurity. They derived from the common Indo-Germanic root *bheidh-. This term encloses the meanings from persuasion, reliance, faith, confidence, and trust, to tie and intertwine.

For the formation of pistis and the related meanings of 'faith' and 'trust,' the mutual influences of persuasion, obedience, and following were important. In the political writings on the State by Plato, pistis is inscribed with meanings of faith as a form of cognition in opposition to knowledge (Plato 2000). It expresses a state in which the soul has the capability to discern the physical world. This faith is the basis for a firm fundament. Plato considered this of paramount important because 'ordinary' people do not, and cannot, discern the truly good but they can be orientated to it which is a basic condition for a justified state.

In the doctrine of the Stoics, pistis is a virtue next to pietas and instititia. Pietas and apista are distinguished as true and false assumptions. Apista represents a lack of faith which is embodied, thus materialises in the individual by a belief in lies. The problem for the Stoics was to reach a form of unshakable faith through examination

\footnotetext{
${ }^{2}$ This approach is therefore different from Desportes (2006), who only raises linguistic questions.
} 
and approval. In other words, the Stoics sought a way to enable certainty. Pistis is the firmness of the mind (see Thomas 2001). A person who possesses pistis is informing us about the truth, and could give advice and orientation to others.

Orientation through moral principles which is based on a complex philosophical programme represents the meaning of pistis, even in further concepts. Examples could be found in the writings of Parmenides, in the writings of Aristotle about friendship, or in the virtue dogmatism of the Stoics. Pistis was thus a term for integrating Greek society (Seidl 1952). Apista expresses doubt, a doubt that refused the moral principles and their philosophical basis. The wise man had no doubts and was rational in his mind.

These Ancient Greek developments were highly influential with regard to later meanings (Gruen 1982). It is especially relevant to the conjunction of trust with states of cognitive contingency. Contingency was seen as dangerous to the mind because it had the power to tangle people's decisions and to weaken a stable mind. This psychological connotation is still currently in use and is identifiable in phrases such as 'trust yourself' or 'be confident'. Although Plato and the Stoics had the political or moral order in mind, they did not develop an understanding of trust within social relations.

Roman Latin had two words for trust—fides and fiducia. These terms were highly interchangeable; their meanings were only slightly different. Fidcuia appears mostly as 'reliance on' which indicates a form of active trust. "Nous noterons enfin que fiducia est très clairement l'action de se fier á la confiance active" (Freyburger 1986: 31). Following this idea, Freyburger formulated the notion: "Le degré zéro de la racine est représenté par fides, fidelis, avec les dérivés fideliter, fidelitas, infidelis, Fidius (dans Dius Fidius et, en une composition que nous examinions plus bas, perfidus, perfidia, perfidiosus)" (1986: 31). Fiducia is a term which has an active meaning, a stable and sure trust. Trust, or rather, fiducia, exists in two forms: as selfconfidence and trust in others (their physical and psychological facilities) (Engels 1969). Self-confidence has an evidently positive connotation. It is especially praised and enhanced by politicians, artists, soldiers, among others. It has the connotation of calm and serious consideration. People who were considered to have such a character were held in high regard by the Romans. This active attitude enabled the foundation of a new trustful relationship, and is the bedrock for fides. It is an assumption and condition of fides. This aspect is reflected in the writings of Heinze (1972) and Fraenkel (1916). Fraenkel emphasises fides as a guarantee or, in other words, as all which is reliable. Heinze, on the other hand, does not iterate fides as such an objective facility. It is a wish; trust is a gift and is based on mutual appreciation. Gérard Freyburger's notion encompasses both these aspects (1986). He distinguishes fides into an active and a passive version. The first one 'confiance que je donne' indicates trust as an act in which one displays something towards somebody else. The second one 'confiance que j'obtiens,' represents the trust which one obtains or, rather, reaches themselves. With the active variation Freyburger denotes trust/faith and with the passive variation guarantee/reliance.

In the Roman Empire these concepts of trust were particularly important for patron/client relations, as these relations formed one of the main organising principles of reciprocity in the Roman Empire (Hölkeskamp 2000; Callies 1989). 
The relationship between the patron and his client was not secured in law. The "[...] historical Roman patronage is a moral not a legal relationship" (Wallace-Hadrill 1989: 66). Here fides and fiducia were social status symbols of a person. Accordingly, the Gallic aristocrat Paulinius of Pella formulates: "when my house was happy and prosperous [...] and when the display of my rank was very important, magnified and bolstered by deferential crowds of clients" (WallaceHadrill 1989: 64f.). The rank was a symbol that displayed that a person was trustworthy in the sense one could rely on their word, and represented stable and secure social relationships. This produced a reliable order for the present and the future and was thus a sign of high status. The stabilisation was therefore mutual. It was a secured social relation not only for the client, but also for the patron. His status was predominantly based on his reputation and dignity which included certain moral standards; this denoted an acceptance of the social order. It was precarious and unwise not to fulfil social obligations as affront and disgrace could follow (infamia and ignominia). "Ignominia based on an announcement of a public institution and infamia on the public opinion" (Kaser 1956: 227). "Infamia [...] was largely directed to the punishment of a breach of trust" (Greenidge 1977: 62). Further opposing terms were perfides and fraus (see Heck 1889; Niemeyer 1891; Göppert 1892; Berger 1953: 471). The Ancient Greek notion of trust in relation to cognitive contingency was broadened to include social interactions. Trust related to bridging situations of double contingency. It had an important social function within personal relationships. It was addressed to a specific behaviour to ensure reciprocity.

A central question for the Christian religion was the personal certainty of faithits predestination (Weber 2001). In this tradition fides and fiducia were divided into two different terms. Fides became the leading concept of Christian religion, the faith. Faith came to mean an acceptance of the Kerygma. Only this was the basis for God's compassion. The relation to God, however, does not have the form of an interaction. In front of God one does not have any standing. Trust (fiducia) has a subordinated status. If it appears, then it is not with the meaning of trust in God. Moreover, it is a hopeful trust, a trust which is focused on God's miracles. The formation of the term fiducia was influenced by the translation of the Bible from Ancient Greek into Latin. Fiducia became the equivalent of parrhesia (Jaeger and Eughien 1957). As a result, new meanings were incorporated into understandings of trust. Parrhesia took the meanings of free stand and free speech. A person had to be morally free in order to obtain parrhesia. This idea of free standing is the same as in the Hellenic-Jewish tradition. Abraham and Moses were people who had parrhesia and stood in front of God as friends. This tradition particularly emphasised the aspect of correct behaviour and acceptance of social conventions. Parrhesia is a form of boldness in a positive sense. Fiducia appears here with an eschatological meaning (Engels 1964). It facilitates us to survive in a chaotic world. In suffering and with patience the good Christ can have confidence. Without any fiducia, the pressure of fear would dominate our lives. Augustine's writings accentuate the significance of fear (timor) in Christian life (Ljunggren 1921: 127). He warns of cognitive security as a form of mental carelessness. Delight has to be seasoned with 
a pinch of uncertainty. Fear and trembling are the fate arising from the good Christian. Augustine defended himself explicitly against self-confidence, and from trust in secular entities such as money, reputation, or powerful friends. Trust (fiducia) is related to veridicality. This powerful character derives from parrhesia. Fiducia invigorates people. Being in the grace of God means trusting God and this enables one to resist the fears of the world. This is the result from following the path of God. Gregory the Great continued this shift with a stronger notion of fear in order to strengthen faith. ${ }^{3}$ Certainty can be reached only by human deeds, notwithstanding the fact that people cannot know that they potentially have a vocation for a life in the next world and that they are not lost in total fear. The confidence of faith (certitudius fiducia) is what enables the belief in Christ to survive in a chaotic world. This fiducia is caused by human deeds. The reduction of trust dates back to a Greek version of a cognitive facility that experiences the incorporation of a circuitous social connotation (Hunzinger 1906: 43ff.). In the scholastic world, these nuances are dealt with in deeper philosophical debate. The introduction of the temporality of trust and the orientation of trust on a future horizon are the major innovations.

In the Franciscan school, the certainty of faith (fides) was not founded in a philosophy of the world outside (science). Rather, it was based on the logical principles of faith itself. Resultant from this was the conclusion that faith was not a concern of rationality. Although faith influences the will, fides does not appear as a personal relation to God. Faith is rather the fundamental aspect of spiritual life. The object of faith can no longer be encompassed in a concrete personal relationship and therefore fides is not a term that expresses a distinct personal relationship with God. At this time, reward and merit are mutually reciprocal. To strive for these rewards opens the way to holy grace and thus produces the possibility of acquiring the holy promises. This path of personal acquisition influences one's future character. Fiducia as trust is different to faith. It is not related to faith but to spes (hope) and therefore it is oriented to the future. ${ }^{4}$ Spes can be seen in the writings of Bonaventura and is oriented towards two aspects, God and His offerings. If Bonaventura is referring to God, then he speaks of fiducia and to his offerings of exspectatio (expectation): "The third part of the perfection of the fear of the Lord consists in the perfect firmness of trust; because the fear of the Lord is a tower of firmness and of trust". 5 God's charity is not free from prerequisites or requirements. Hoping for God's grace without any merit would be praesumptio (arrogance). Fear appears in this context as a force which ought to keep sin away, whereas hope is the prospect of God's promise, albeit God may not accept the merits; ultimately, the premise of this philosophy is that no one can be certain. Only in trusting God is

\footnotetext{
3 "With fear the Christianization has to begin, fear has to accompany it, fear has to complete the sanctification" (Ljunggren 1921: 158, translation by the author).

4 That combination is during the Scholastic a common version (see Jaeger and Eughien 1957: 239, footnote 2).

5 http://www.franciscan-archive.org/bonaventura/opera/collat2.html [13. November 2008] "Tertia pars perfectionis timoris Domini consistit in perfecta fiduciae firmitate; quia timor Domini est firmitatis et fiduciae turris". St. Bonaventure of Bagnoregio: Conferences on the Seven Gifts of the Holy Spirit: Conference II: On the gift of the fear of the Lord, Paragraph 21.
} 
there a chance to overcome this uncertainty. Trust is not, however, an absolute certainty, it is temporary. Fiducia does not create a new will or gives air to breathe. Uncertainly and hesitantly it follows in the footprints of the sanctification. Salvation is mixed with doubts and fear. Fiducia is the inner relation between hope and faith, with an orientation towards the future.

This notion is further stressed by Thomas Aquinas (Gauthier 1951: 272ff.). Contrary to the teachings of the Franciscans, in his writings the soul is not entirely a part of the will and affects, it is a part of the intellect. Faith is not inspired by a mystic act, it is an empirical process. The 'impetus for faith' is a result of a superficial revelation which originated from the Bible. A proof of agreement is membership in the Catholic Church. Moral judgement lies in the hands of the priests and is legalized by a worldly authority. The probable means of reaching grace are penance and indulgences. With this reorganisation, the meaning of hope changed. It became the force which oriented moral life on earth. Contravening that path would be punished with fear. Hope would be specified by merits. An important fact to highlight is that Thomas derived the certainty of hope from faith, although fiducia is plainly subordinated to spes: "Trust is through firm conviction reinforced hope". 6 This idea was foreign to the etymological tradition, although it was common at that time. To follow God's path there was the need to discern that it had already begun and that it was possible to remain on the path. In Aquinas's definition, fiducia was the beginning and the force of hope. It was an effect which would be revealed if one's heart was in the right place. Diagnosis of this state was not an issue of someone's own belief; this was the realm of the priest. Faith is dependent on the right disposition with regard to deeds enacted. By acquiring the holy notions, trust will be the result, which accepts God as the creator of the world. It could be secured by the constant God as opposed to fallible humans (Basse 1993: 90). Fiducia is therefore the trust of strolling on God's path.

Besides the discovery of temporality, the problem of a relationship between God and the people is solved by abstraction. In this context the idea of abstraction is generalised. It reflects a principle that people could rely on, something that is not addressable, i.e., personal. The different meanings of trust, therefore, delineate into two forms: a more personal and a more abstract version. Both, however, stress the temporality of such relations. Trust is, in this sense, not a relational term. Rather, it is a medium that can support the connection of social acts within an uncertain future.

The aim of this chronological foray has been to clarify how trust has evolved out of the rich meanings of historical semantics while approaching contemporary society. The next chapter will illustrate how these concepts are integrated within the general social structure and the theoretical distinctions that can help broaden our understanding of that distinction.

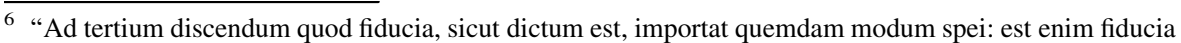
spes roborata ex aliqua firma opinione/Confidence, as has been stated, implies some form of hope: for confidence is hope strengthened by a firm supposition" (Thomas 2006: 2a2ae. 123-140, 129, 6, 3).
} 


\section{Theoretical Considerations on the Distinction between Personal and System Trust}

With the differentiation of society into subsystems, religion struggles to dominate the self-descriptions of society. Interpretations of nature, history, and the world vie with religion to claim to fulfil that function. Concurrent and parallel issues of organising social existence have emerged with these changes to the structure of society. The problem of double contingency has re-appeared. Whereas older European societies could mobilise broad solutions through an outer-worldly moral, political, or religious order, contemporary society has lost its Archimedical point. Social contingency can no longer be exclusively directed to these issues. Rather, a solution has to be found within society itself. Trust has become increasingly closely related to the principle of self-reference. Future evolution of trust could, moreover, resort to a rich semantic tradition. An oblique glance at evolution theory could be described as pre-adaptive advances. Certain pre-existing dispositions which have remained unused, could now potentially direct further formations of social structures within new contexts. The most prominent social structures in contemporary society are interactions, organisations, and functional systems in such areas as economics, religion, art, education, mass media, politics, etc.

Thomas Hobbes first elaborated on this problem of social contingency. Social contingency is based on ambiguity. Ultimately, people's actions are uncertain and cannot be predicted. This can have wide-reaching and significant effects. A failing social reciprocity, for example, could lead to war. Trust functions in this context as a temporary disregard for contingency and, at the same time, as relying on contingency. "Trust is a passion proceeding from belief of him from whom we expect or hope for good, so free from doubt that upon the same we pursue no other way"(Hobbes 1994: 53). The future can cause delight or misfortune, so other options or alternative should not be ignored. In this case, trust gains a new companion in the form of mistrust. Admittedly, any future outcome requires a degree trust, but if there is a doubt about the way and about the endeavour, one should look for other options.

In the case of Thomas Hobbes, it is pertinent to speak of personal trust. Hitherto, especially in the older Roman semantic tradition, this relationship was socially restricted to patrons and clients. This limitation is no longer valid or applicable. Personal trust can be found between mother/child, doctor/patient, and buyer/seller or between friends. Whether the relation is asymmetrical or symmetrical, trust is always present in some shape or form. The need to trust can be found, therefore, in any social situation where a form of reliance or dependence on someone else is needed. In these contexts trust works as a relational term with reference to a particular social address, i.e., a person. Hobbes accentuated the temporal character, as did the theologians. People can act differently and deviate from expected behaviour, thus trust is tenuous and not permanent. The on-going character of trust reflects temporality in two directions. Trust does not exist as something given, something unchangeable, and trust can only be stabilised over time. This temporal dimension indicates the need to withhold other possibilities. Hence, the relationship begins because one person's vulnerability functions as an opening to a trustworthy 
relationship. Achievement of this is a slow and intermittent process. An initial sign of trust by one person is followed by a trustworthy sign from the other person, and vice versa. Trust is therefore built on addressable acts and can also be withdrawn because of these. The quality of these signs, of course, can differ greatly (see Bacharach and Gambetta 2001).

Even though there is a very similar discussion in the writings of John Locke, he elaborates on a different form of trust. For Locke (1954: 212; see also Dunn 1984), the boundaries of society cannot be found in tradition or normative consensus, but only in trust. Trust, or rather trustworthiness, is the only capacity which can legitimise human promises or cope with "the contingencies of individual disposition" (Dunn 1984: 290), the hazardous social milieu and the vast possibilities of a society. 'To trust one another' is a priori essential for the existence of society, and it is what makes human society possible (Locke 2002: 33-39). It is fundamental for the existence of moral principles and positivistic law. A world without trust would end in riots, plundering, or worse. It could simply cease to exist in any identifiable form. To prevent this, there is a need for a general compact of trustworthiness. ${ }^{7}$ After this choice is made, other concepts, such as justice, can be realised. The compact is withal not particularly understood as a relation in the sense of an interaction between two concrete persons, such as a seller and a buyer. For Locke, trust reflects the smooth and reliable functioning of certain social principles because it legitimises the expectations of others. ${ }^{8}$ Such principles include the law, moral principles, and the exchange of goods, all of which are a basic characteristic of society. Resultant and emergent from these ideas is 'tacit trust,' of which Locke speaks (2002: 171, §§ 1-5).

The normative and familiar worlds of a religious order as the main principles that organise contemporary society have vanished. Contemporary society is highly differentiated, which Emile Durkheim noted was clearly marked by the division of labour. This world is much more complex and contingent than the former one. Faith and forms of personal trust are no longer able to bridge the widening gap of strange and distanced social interrelations. ${ }^{9}$ Trusting other people does not include a wider social converse such as the principles of law, politics, art, or science. Nevertheless, it is necessary in this expanding world to integrate unfamiliar or foreign horizons in our own behaviour. Trust becomes more functional and specialised within certain types of communication and therefore reflects and affects the reliability of other communicative acts. It is, so far, not a form trust in a familiar person, but a form of trust in the functioning of social reality or certain social values, e.g., money, power, truth, etc. (Lewis and Weigert 2005). This form of trust has another temporality. It is not built upon individual interactions in mutual and recurrent experiences. Rather, this type of trust is built on continuing feedback of functioning or not functioning. This form of trust is easier to establish but more difficult to control or to transform

\footnotetext{
${ }^{7}$ Locke rarely uses the word contract; compact and agreement are more common.

${ }^{8}$ In the case of political power, see Locke (2002: 136).

9 A notion of trust develops, which is closely related to time, in particular to the future of social relations. The future is, however, not secured through normative or religious patterns but through open endeavour (no knowledge exists to determine the future). It is under these conditions that trust and risk become partners (see Simmel 2004: 480).
} 
into distrust. ${ }^{10}$ What are signs that the economy or the political system is no longer working well, and what about our trust in the signs? All this makes confidence (or system trust) diffuse and thereby resistant to breakdown. It can cope with individual disappointments. Confidence should thus not be confused with familiarity or routine. This form of trust also reflects the contingent principles of the social world that could or could not be, and is marked by other decisions and other options.

Summarising these two semantic trends it is possible to say that trust casts out expected future horizons which regulate present actions. In this instance, regulation indicates a counting or computing of social contingency. The temporal dimension is limited, and trust is not given forever or indiscriminately; it is given because it can be withdrawn and replaced by mistrust. In situations of personal trust, this process is highly individual and depends on the sophisticated management of specific signs of trustworthiness. A more diffuse form of trust, known as confidence, has developed as a consequence. It is, in a temporal sense, both easier and quicker to establish, but it is more abstract. It can, therefore, cope with individual disappointments more easily. Even though confidence is widely in use, forms of personal trust are still significant in societal relations. This is especially true in recurring social settings where it is necessary to cope with a level of personal contingency. Personal trust is based on forms of interaction. It is obvious, however, that the current social order cannot exist based only on personal trust and that confidence is highly necessary for coping with the abstract mechanisms of contemporary society.

The conceptual version of trust as personal or as confidence is still problematic (see Smith 2005). The term 'personal' denotes psychological, mental, or emotional capability, while 'system' refers only to a very limited slice of social reality. This paper does not claim that trust has few mental consequences; the focus is on a societal framing of trust. With these psychological connotations, another term comes into question. Trust that is personal or that is confidence (system trust) is often understood as a relationship between particular people or between particular people and particular things. This approach ignores the complex attribution problem which lies behind the construction of labelling references such as people and organisations (collective actors). It is vital that this point is acknowledged and addressed. Attribution theory highlights how references have to be constructed so that utterances or other social acts can be attributed within the processing of social acts (see Jones and Harris 1967; Jones et al. 1971). This essentially means that these references are not provided and are therefore contingent upon social constructions (see Guiot 1977). To claim relationships between these facets (e.g., personal references), further social concepts are necessary. Hobbes recognised that trust underpins these constructions in a relationship between people when he emphasised the double contingencies of the social interactions of the social world per se. Social acts of attribution in this case can have a particular or universalistic notion; in other words, they can attribute something concrete (e.g., people and organisations), or they can attribute something more abstract (e.g., social principles, social media,

\footnotetext{
${ }^{10}$ Whilst it is a commonly held view that the general confidence in the economy is low, this should not reflect on general principles of economy at large, rather on the localised markets and specific profit seeking strategies.
} 
money, and power). However, to describe personal trust as concrete and confidence as abstract would be misleading. We know that relationships with people can be very abstract and that relationships with social concepts, such as love, can be very concrete. This always leads to a formulation of 'more or less,' which is imprecise and variable. The following paragraph examines two other distinctions in order to solve the theoretical problem of social attribution.

The attribution theory concept of concrete versus abstract can be replaced by a more insightful and helpful one: addressable versus non-addressable (see Fuchs 1997). The advantage of this distinction is justified by two aspects. An address is truly a social construction, a communicative attribution, used to refer to somebody (e.g., people or organisations). This attribution constructs social actions and, in a sense, one can speak of an acting person or organisation. On the other hand, functional systems cannot 'act' because they cannot be attributed, as they have no social address. One cannot write a letter to the economy or to society. Society has no motives or fixed intentions. Only people or organisations can be addressed. In addition, there is concurrent possibility to refer and direct other people or organisations to build other social chains. In consequence, because trust can be conditioned, the contingency can be reflected in other addresses. One result of this is that other possibilities and other complex alternatives appear. These deliberations lead to another distinction, which specifies and influences the former one. 'Personal' trust will be defined as trust that can be conditioned, while 'system' trust/confidence will be identified by a contingency that cannot be conditioned. ${ }^{11}$ The application of these two dimensions of trust also leads to a different way of dealing with distrust. Within conditioned trust, the sequential structuring of time plays an important role, such as the choice of distrust will only be excluded with each mutual step. Any wrongdoing can quickly destabilise this process. Unconditioned trust, or trust which cannot be conditioned, almost inhibits distrust. ${ }^{12}$ Sometimes there are problems and disappointments, but mostly this situation is quite stable. Therefore, trust reaches the general level of 'whether/or' and refers to non-addressable principles, such as money, power, or truth. This also has consequences when describing a seemingly natural increase or decrease of confidence. Increases and decreases, however, do not refer to the intensity of trust, but to the anchoring or embedding of this type of trust in social reality. Thus, when speaking of a decrease, the paper does not describe a lowering of confidence, but rather that the social organisation of action and communication uses other modes of structuring social reality, such as forms of personal trust (Southern Italy is still a prominent case for this phenomenon; see Mutti 2000).

With these theoretical considerations it is possible to reformulate some semantic meanings within the framework of the distinction between conditioned and unconditioned trust. In terms of the time dimension, the two sides function under a different temporality. Forms of conditioned trust, as described above, need many

\footnotetext{
11 Conditionality is here used in the sense of limiting or constraining as a general structuring (see Ashby 1968). In relation to language, it is important to note that conditioning refers to a specific tradition of system learning deriving from behaviourism and not to a state or legal application, like an unconditional surrender. This paper deals with the term conditioning in the sense of structuring contingent situations.

${ }^{12}$ Luhmann speaks therefore of confidence than system trust in his later oeuvre (see Luhmann 1988).
} 
sequences, the comparison of results, and negotiation with minor disappointments. Unconditioned trust is easier and faster to learn; as long as it exists, it tends to work, and therefore this reinforces the trust. In this sense the older distinction, i.e., active versus passive trust can be reformulated. In terms of the fact dimension, and here focusing on the management of risky information, the distinction of security/doubt can be replaced. Both forms are accompanied with possible disappointments. However, this is not a question of an enlightenment of the mind. It is not a question of simple contingency and thus a question of reliability; it is created by the double contingencies of all social acts and only in this case trust is needed. "When the car breaks down we might be angry; but when a friend lets us down we feel betrayed" (Holton 1994: 67). Focusing on the social dimension, the distinction of conditioned/ unconditioned trust incorporates the theory of concrete/abstract relationships. Forms of conditioned trust handles addressable social constructions such as people or organisations, whereby unconditioned trust deals with non-addressable forms of social reality such as social principles and social media.

With these historical and theoretical considerations, a bed-rock for additional empirical research has been prepared. For this reason the following chapter addresses two main occurrences - the Watergate Affair and the changes in Eastern Europe in 1989. The purpose of the chapter is not to explain these events but to explicate the interplay and functioning of the distinction between personal trust and confidence. The cases have been chosen to exemplify the circular process of growing personal trust leading to system mistrust and how personal mistrust can be transformed into confidence. The aim is therefore to explain these events in full detail but also to demonstrate the dynamic of the distinction of trust/confidence and the mutuality (as positive and negative feedbacks) of these two forms. ${ }^{13}$

\section{The Relation of Personal and System Trust within a Crisis: Revolutions of 1989}

The political changes in Eastern Europe around $1989^{14}$ were caused, according to popular diagnosis, by a general lack of the commodity of trust (Sztompka 1996a) that still continues today (Mishler and Rose 1997: 419f.): "Endemic distrust, appearing at all levels and in all regions of social life, remains a reality 5 years after the fall of real socialism" (Sztompka 1996a: 47). ${ }^{15}$ This general depiction overrides

\footnotetext{
13 Another more recent case, which would also be of interest, is the economic crises and financial turbulences in 2008 (see Tonkiss 2009, Earle 2009). A group of individual banks were drawn into the spotlight. They did, however, not cause a collapse of confidence in the economy but events led to undermining the trust in banks, in particular between them.

14 The paper focuses mainly on Poland, GDR, and Hungary. Other countries such as China or Romania are mentioned as well, but to a lesser extent. It also only addresses the role of trust before 1989 (for role of trust in post-communist nation-states, see Marková 2004; Mishler and Rose 2005; Sapsford and Abbott 2006). The conference 'Trust/Distrust in the Soviet Union' at the UCL in February 2012, did not address the changes in the 1980s. Perhaps, the upcoming conference 'Trust and Distrust in the Eastern Bloc and the Soviet Union, 1956-1991' at the UCL in September 2012, will provide a different perspective.

15 Sztompka is surely one of the key authors in the area of trust with regard to Eastern Europe. However, his research is mainly concerned with the creation of honesty and trust in post-socialist nation-states and not how trust contributed to their collapse. He simply claims that pre-1989 there was distrust on all levels
} 
the co-productive impact of the distinction between conditioned and unconditioned trust. ${ }^{16}$ Instead, it can be illucidated that these two dimensions had to work and operate together to influence political change. While developments in Eastern Europe are often referred to in 'incidental' or 'eventful' terms such as '1989' or Wende, they did not happen overnight and were resulting from a growing trajectory of destabilising factors. Change was accompanied by protest movements, the formation of non-official parties, distribution of pamphlets and other media (including the violent occupation of stations controlled by the government), intense demonstrations, the increasing influence of the Church, great waves of refugees, and political infighting. It is immediately evident that without any form of trust, these social commitments would have not been possible.

Although Eastern Europe had faced several unsuccessful political uprisings, discussions of alternatives remained within the private zone; they were themes at the dinner table, and were discussed with friends and colleagues in bars and pubs. They were shared with a familiar group of friends with no ambition for open conflict and there was little confidence that alternatives existed. ${ }^{17}$ Yet, due to their peripheral status or strength of their weak ties these networks had diverse and connecting effects on other networks (Granovetter 1973). Someone in such a network was part of another network or was present at some other meetings, or people with greater political weight or ambition who perhaps had significant knowledge of the political scene, joined. The networks were growing slowly secretly and, with them, there was a growth in the level of personal trust. The networks were made up of selected people, people one could trust as they shared the same beliefs and disappointments. The networks became a circle that began to make a difference between their own ambitions and the ones in the official political arena (see Pfaff 1996).

In countries such as Poland, Romania, and the GDR, religion still enjoyed a form of unconditioned trust (see Cordell 1990; Pollack 2002; Borowik 2002). ${ }^{18}$ Although religious institutions had lost many members in Eastern Europe, they still enjoyed an image of preserving their own values (Burgess 1997: 60). Religion also evoked the positive trait of being trustworthy. ${ }^{19}$ Firstly, religion still represented democratic

\footnotetext{
Footnote 15 continued

of society (see Sztompka 1996b). This picture results from an overemphasis on system trust and not enough attention being paid to the personal networks and similar structures in which personal trust is based.

${ }^{16}$ It also does not recognise the different outcomes in China after the counterinsurgency of the student revolt.

17 Former uprisings in the GDR, Hungary, Poland, and the Czech Republic had been suppressed militarily.

${ }^{18}$ For the importance of trust in relation to the Church and the state in other East European countries see Mureşan 2006.

19 In China, the university and some intellectuals performed a similar role (see Francis 1989; Gu 1998). The universities and intellectuals were mainly based in the urban centres which caused a rather limited spreading of trustful networks especially to the remote rural areas of China. The political centre or the higher levels of the government still enjoyed trust, whereby the lower levels were distrusted. Therefore, some of the dissatisfaction arose at levels which were not the ones criticised by the student's revolt (see $\mathrm{Li}$ 2004). Thereby spill-over effects were limited.
} 
ideals separate from those of the state. For example, in Poland there was the "bad" state and the "good" patriots associated with the Church (Borowik 2002; Kochanowicz 2004). Secondly, such basic religious values spoke to the hope and aspirations of many, and simultaneously represented and articulated general symbols of trustworthiness. Thirdly, religious institutions provided a space for alternative groups and an alternative political public. ${ }^{20}$ Although the movement may have initially seemed all-inclusive, in reality it was not. As aforementioned, it consisted mainly of loosely coupled networks and access to early dissident groups was, due to the ever-present danger of intruders such as spies, highly personal and highly limited. Secure and lasting trustful relationships require time to become established; however, due to the specificities of context, in this case, these relationships were built quickly. The wider horizons of the Church provided a neutral ground. Within these trustful places, a broad set of individual incentives encouraged people to participate and as a result, other trustful, mainly personal, networks could be established to a much greater-and far quicker-extent. ${ }^{21}$ Loosely coupled networks could occur on a permanent basis and form even stronger bonds. Information, belief, and the need for change and choice became their theme tune. These networks had two effects. Growing personal trust between individuals and small groups caused internal disbelief and disappointment with actions that were occurring in the official political arena. A distinction between us (the good and trusted people) and them (the evil system) began to emerge. This was later expressed as "Wir sind das Volk" ("We are the people"). Every political decision made outside such networks was questioned. The political system became polluted with suspicions of contingency in every act. Subsequently, these networks provided a safe and trusted haven from which contingent choices could be reflected and converted. The second effect was that very practical tasks could be organised easily, e.g., locations and times of demonstrations, speeches of opposition, information about police controls or arrests, etc. Through these personal networks, spontaneous demonstrations could be organised which were highly visible to a wider, similarly

\footnotetext{
${ }^{20}$ In Hungary the development was rather different. In many of the East European countries there appeared a so called second sphere alongside economics, politics, culture, publicity, and so on. The political liberalisation during the $1950 \mathrm{~s}$ in Hungary meant that in later years this sphere was probably the most developed within the former socialist countries. These spheres were mainly organised through patron/client networks of mutual trust. The Elite and the general public could establish a sense of general trust, and a more liberal form of economic, political, cultural, etc., actions could be practised. More and more of the institutional decision-making mechanisms were hoisted into the sphere of these patron/client networks. When the political system struggled in the $1980 \mathrm{~s}$ and then collapsed, the transformation could rely very much on these networks. The high inclusion of the members of the networks excluded others and the implementation of other social structures. This contributed to forms of nationalistic (family semantics) commitment and intolerance (see Seligman and Füzer 1994). This difference and focus, whether to trust or to have confidence, seems to be a problem in the work of Robert Putnam (1992). Therefore, he does not consider in a sufficient way that there is no lack of trust in south Italy. On the contrary, those thick networks of trustees undermine the institutional structures and as a proof of trustworthiness, they are avoided. Also, the higher levels of administration are left as an out-group because they are viewed as untrustworthy. Putnam does not recognise, due to the missing separation into trust and confidence, that trust can cause forms of social sclerosis.
}

21 Such networks are the main sources for overcoming the barriers to participation (see Klandermans 1987: 527). 
disappointed public. As a result, more citizens could therefore be mobilised (Opp and Gern 1993).

In most countries the political establishment lacked the knowledge or skill to cope with this rising movement. The uncertain future of these outcomes was wiped away with an emphasis on the 'glorious' past, (helpless) ignorance or even violent suppression, or cosmetic improvements. This mostly resulted in governmental political stagnation despite pressure from below, and had significant and pervasive long-term impacts. The inner blockade of the ruling organisations resulted, in the public view, in an amalgamation of the political principles and the representing organisation (see Fehir and Arato 1991; Staritz 1991; Unverhau 1999). This had two main effects. Firstly, the withdrawal of trust in political parties did not result in the possibility of other contingent options. Therefore, socialist principles or rather the political system itself were increasingly questioned and thus other contingent choices, with the example of the West at the front door, appeared. A lack of confidence in the entire political system was growing in the networks, as the possibilities discussed within them could never be practically implemented in the political system (see Horváth and Szakolczai 1992; Hough 1997: 61; Maier 1997). Growing disaffection, in this case, meant that severe disappointment with social expectations were no longer individually addressable or were circumscribed to local issues. $^{22}$ The distinction of trustworthiness existing within the networks, and political contingency functioning as the norm outside these networks, was accumulating; this tended to create wider effects within the greater social structure, with a general tendency to create spill-over effects, ${ }^{23}$ e.g., with regard to the economy, culture, etc. Following this argument, the impossibility of a withdrawal of trust in certain political parties or members of the government, stimulated an increasing gap of between expectations of the political system as a whole and the actual practical reality of the decisions it made (see Hirschman 1993). At the apex of disaffection all attempts by the East European governments to solve the problem and install new political faces in important positions and effect some liberalisation, only seemed to prove that more contingency was possible (these developments seem to be similar to those of the so-called Arab Spring, see Warf 2011). This was the final stage. The networks that had come to be perceived as trustworthy became a power in their own right. Due to this emerging power, people began to ask for change and revisions openly and any acquiescence to their demands only served to prove their power and their right to ask for more. To build trust, the political system had to overemphasise its trustworthiness, to ask for confidence in its general existence; this inflated trust which was then proved wrong as every approach seemed to prove its unreliability. On the other hand, emerging possibilities of other

\footnotetext{
22 The networks of personal trust not only contributed to an erosion of confidence but also prevented errors of the system from being transformed into issues of self-confidence, i.e., it is their fault and not mine (see de Vries et al. 2003).

23 That has similarities to a panic which is caused by the overcoming of specific thresholds. Like it is known from a mass panic, one only runs when 20 run but someone else runs not before 100 run. If one of these barriers are breached a mass panic starts. Thus, a panic is not a linear accumulation but marked by a crossing of such border step by step. With more trust, more people feel secure to speak up and when more speak up others feel secure to join them and so on (see Mayntz 1988).
} 
new forms of political trust remained unused, as the personal networks were the only reliable basis of trust that could lead through the storm, but could provide no further confidence. The medium of trust could then only be re-established by its complete stagflation.

Talcott Parsons distinguishes between inflation and deflation of communication media in cases when it is overused or when it is not used enough (1969: 463ff.). An inflation of trust is therefore possible if its performance is too excessive and more trust is presumed than is actually produced. Deflation represents the opposite, in which the opportunity to create new trust remains unused. The inflation of trust is expressed through the devaluation of its symbols and signs and is accompanied by increasing uncertainty. In the case of deflation, the social conditions are too limited; the use of trust is barely practised. Further communications are restricted because it is believed that any results will be ineffective. However, these modes of inflation and deflation are more complex than the aforementioned description suggests. In Eastern Europe, trust experienced both inflationary and deflationary trends simultaneously. The governments in Eastern Europe stressed a high need to trust their decisions with little questioning and stringently opposed raising the contingency of political communication; thus there was no chance that with strong disappointments, visible consequences would follow. At the same time it became impossible to establish trust in situations where it had become necessary (the movement in Eastern Europe therefore had to establish networks of personal trust to accommodate this dearth). This double drift, which could be identified as a form of stagflation, devalued trust in both directions (see Weatherford 1984). Spill-over effects were then highly likely, with contingent horizons appearing. If one option became a preferable selection, the destruction of trust could lead to an implosion emphasising the new path. The wind of change had become a storm.

The second case in this paper had its starting point in June 1972. Five burglars were caught in flagrante delicto during a break-in at the Democratic campaign headquarter in Washington DC, which was based at the Watergate Hotel. Investigations conducted by the FBI, the Senate Watergate Committee, the House Judiciary Committee, and by the Press, revealed that this burglary was directly or indirectly related to the Committee to Re-elect the President. Further inquiries exposed other misdeeds and misdemeanours, and in March 1973 the American public was exposed to these findings. This was followed by the public broadcasting of the senate hearings. The American public were then made aware that President Nixon secretly recorded most of his conversations and there was an outcry for these to be made available to the public. When the content of these recordings was made public, it was clear that Nixon had been intimately involved in the conspiracy and cover-up activities since his inauguration. Before impeachment proceedings were initiated by Congress, he resigned. The Watergate incident is described as the most serious political crisis in the United States since the Civil War (Alexander 1995). Although this rhetoric was doom-laden, the final outcome did not result in a total crash of the entire political system. On the contrary, it reinforced confidence in the system of political communication. The "symbolic, moral lessons of Watergate had profound and relatively long-term effects [...] they reinforced trust in democracy, in the constitutional system upon which American government and society rests" 
(Alexander 1995: 1369). How can this change from a rather minor incident to a large-scale crisis be explained? How could the crisis have reinforced confidence in political communication when it became evident that the American president was involved in illegal conspiring acts?

After the initial the break-in, there was no public outcry, nor was there a deluge of questions regarding the mode of the political modus operandi. Instead, party politics were depicted as steered by power and interests. The break-in was part of such a power play and therefore seen as 'just' politics (see Alexander 1984: 304). As more and more detail was revealed, what had been a rather localised event infected other areas of the political arena. The President and his aides became involved in the revelations. The event became associated with the highest political spheres and therefore political communication was drawn into the spotlight (Lipset and Schneider 1983: 383f.). Despite the involvement of top level political figures in a conspiracy and further violations of the political rules, the distinction of conditioned/unconditioned trust had a different interplay than had been the case in Eastern Europe. In particular, the role of the mass media and the public broadcasting of the hearings, the polls and other events (Saturday Night Massacre) had a significant impact (Lang and Lang 1980: 532ff.). Another aspect was the overall low level of confidence (low in the sense of being anchored or embedded) in the government (Miller 1974), which could provide no support in the crisis in the sense of bridging the gap. Instead, the declining trust found its self-fulfilling prophecy. As will be shown, this was a one-way track. The growing distrust in the President did not cause a parallel decline of confidence in the political system. The contingency of political communication increased, but this created a period of reflection leading towards greater confidence. Contingency revealed that there was no need to seek other options, or to take other pathways, or to bring another political structure into focus. Instead it appeared, on the surface, that the political principles were worthy of continued confidence as through them the problem could be solved. ${ }^{24}$ Increased attention to legal and ethical issues in government was placed on the national agenda; for example, law schools began to offer courses on legal ethics (Schudson 1993: 157). Indeed, there was a strong difference between the level of personal and system trust. The first one remained quite low, and many US citizens said that they were not proud of their administration although "...they were still outnumbered four to one by those who said they were proud of many things about our system" (Lipset and Schneider 1983: 390). This form of confidence can be distinguished from the trust in the Nixon administration. The President and his aides had enjoyed a personal connection with the public. Any lack of trust on the part of the general public was caused by the simmering idea that certain members of the administration were crooked. During Watergate this opinion increased by $10 \%$ (Lipset and Schneider 1983: 382). "Criticism in the newspapers was usually directed at particular political leaders and incumbents, rarely at the office or the system per se" (Miller et al. 1979: 72). The media contributed greatly to an image of evil men operating in an overall good political system - a system that ultimately

\footnotetext{
${ }^{24}$ For example, this caused an increase in political interest and the voter turn-out during the elections in 1974 (see McLeod et al. 1977).
} 
allowed the media to inform a wider public about further events. The Senate hearings in summer 1973 were watched by millions of Americans. "Watergate became a focused, national public event" (Schudson 1993: 58). These hearings meant that the events of Watergate became more closely related to-and blamed on-individuals and that the ultimate revelation of the scandal was evidence of an effective cultural and political structure. The way that Watergate was dealt with became a symbol. This symbol and all those involved in revealing the scandal were praised as they became identified as individuals who preserved the Constitution, norms of fairness and solidarity. The perpetrators were associated with symbols such as sectarianism, self-interest, and particularistic loyalty (see Alexander 1988: 204f.). Good and evil were identified, and Watergate was linked with the nation's political centre. The President and the men surrounding him were associated with evil and Nixon's opponents were earmarked as being good. ${ }^{25}$

The questioning of witnesses during the live hearings of the Senate was accompanied by routine swearing-in and therefore enhanced the notion that the hearings were imbued with an outline of the law of truth and justice (see Dayan and Katz 1992: 156). The hearings evidenced that those in powerful positions were not immune from the law, and placed these people on the same citizenship level as other Americans. A further impact was made by the media, who remained relatively silent during the trials; newspapers and reporters were seen as keeping a neutral position, stressing the rule of fair play (Lang and Lang 1983: 142ff.; Zimmer 1979). The routine of the questioning, references and gestures were made that emphasised how every US citizen, high or low, rich or poor, should act in the civic republican tradition. It was a public statement that no team loyalty or interest has the right to violate this basis of a democratic society (see Alexander 1988: 205f.). Another aspect was the sometimes dramatic, electrifying, and emotional presentation of the people on screen, i.e., the demonstration that nearly everybody could fight against corruption and a breach of trust (Schudson 1993: 29f.). Other events after the hearings stressed similar points. With the Saturday Night Massacre (Nixon's attempt to fire Cox, the Chief Investigator) personal actions and motivations were questioned. The publication of Nixon's secret tape recordings revealed not only illegal actions by government authorities, but also the personal misbehaviour of Nixon, e.g., his inappropriate use of language and lack of politeness in meetings and talks.

Media coverage contributed to a clear separation of personal and system trust. Watergate became a breach of personal or conditioned trust. It was the President and his aides who were responsible for the violation of basic democratic values. The general public was disappointed by their actions. This made impeachment a logical choice. The personal breach became especially obvious in the context of a boost to

\footnotetext{
25 This personal reference seems to be of great importance in developing trust. There are a few people, who might possess a great reputation. Their expertise and handling of problems (the structuring of contingent issues) leads to the formation of personal trust, e.g., your doctor treating your health problems. The impressions of this modus operandi in its daily business might help to anchor the embedding of confidence. As a result, there is no need to be treated by the same doctor to solve your problems but you can be treated by any doctor (see Rehman et al. 2005).
} 
unconditioned trust. ${ }^{26}$ Personal trust cannot cope with high levels of disappointment and an ending is quickly reached. System trust endures as it has a greater toleration when individual disappointments do not become a massive phenomenon or remain to be personal. Therefore, it can be argued that the intensity of personal trust is stronger than that of system trust as the latter can remain on a lower level (see Parker and Davidson 1979).

\section{Summary}

This paper has argued that the distinction between trust and confidence co-develops in relationship to the inherent logic of the social structures trust/confidence enable and through which trust/confidence are enabled. The overall purpose of this argument was based on the need to work out a clearer conception of system trust/ confidence and personal trust, which goes beyond a simple micro/macro version. The paper emphasised the requirement to pay more attention to the internal, and sometimes contrary, logic of system trust/confidence and personal trust. The paper had therefore to fulfil three tasks. The first task was to provide empirical material which demonstrated that confidence and trust result from the socio-cultural evolution of society and are not like pre-given psychological conditions. This foray into the historical development of the distinction between personal trust and system trust demonstrated that older societies developed no such distinction. Trust remains a source, which is directed towards interactions or mutual relationships. These societies could not gain much in complexity, because distant social relationships had to be framed by such forms of bonding. The second task was to uncover what semantic meanings were nonetheless incorporated into the contemporary version of trust and how they contributed to the differentiation between trust and confidence. Special emphasis was given to a more theoretical re-reading of this material, which highlighted the different logic and social functioning. The paper discussed the issues of addressability and conditionality as key differences and how they might relate to the division of society into different social spheres, the development of organisations, and the role of everyday interactions. With the exemplification of these two forms of trust, it became possible to accomplish the third task of demonstrating how the meaning or development of this medium of social order operates within contemporary society. Two prominent case studies of political crises of trust were selected, which aimed to demonstrate how the different types of trust direct social structures and vice versa. This led to the, perhaps surprising, result that trust is not always 'the chicken soup of social life' (see Newton 2012: 6). Personal distrust can reinforce confidence or personal trust can lead to a growing distrust in the overall political system. ${ }^{27}$ This philosophy formed the logic of the two cases; the outcome of each, however, differed greatly. The growing personal networks in Eastern

\footnotetext{
${ }^{26}$ Not until the Reagan administration was this form of personal trust really refreshed (see Citrin and Green 1986: 446).

27 Deborah Welch Larson reports another similar case in which distrust can create the conditions for trust, the Soviet and US negotiations about nuclear weapons (see Larson 2004: 37).
} 
Europe led to the establishment of personal trust. Within this secured arena people could speak up and oppose the government. This needed time as personal trust had to be built sequentially in a slow step-by-step process (see Semmes 1991; Flores and Solomon 1998). It demanded the possibility of testing it against doubts (Sztompka 1998). Every trustful act needs a certain amount of reflexivity. Results of trust can be invested into further trust. Trust can create a self-substitutive order (Gambetta 1988a). The accumulation of personal trust did thereby not develop in a linear progress, but by overcoming certain thresholds it caused further spill-over effects. Personal networks could be linked with others and instil feelings of communality and security - a safe environment on which one could speak up; this then attracted others to join. Confidence in the case of the political system could be shut off. Watergate followed an opposite logic. The President, his actions and decisions were based on a high level of personal trust and not on a confidence in the political system itself which was actually quite low throughout the scandal. Involvement of a single trusted person, however, revealed progressively that this trust was used against the logic of the political system itself. Normal procedures that dealt with burglaries and crimes were deterred to solve the problem; this was acceptable to a certain degree because the system itself was perceived to be acting in accordance with public interest. This perception shifted through accumulating sequences (similar to the case in Eastern Europe) as the relation of how personal acts of a President and his aides and the democratic procedures of the political system were interlinked were called into question. This led to a questing both of the acts of the President and the broader structure of social systems. The latter caused a distrust in the President but created confidence in the system; sequences of public hearing and media coverage highlighted that the President's acts were personal wrongdoings, whilst simultaneously proving the reliably of the democratic principles which would not absolve or protect even the most important American from the rules of democracy. This inspired greater confidence in the political system. The untrustworthiness of one person could exemplify that the principles and system in which he operated still remained trustworthy and need not be destroyed. ${ }^{28}$

Acknowledgments For helpful comments on previous versions of this article, I would like to thank Christel Lane, Göran Therborn, Frens Kroeger, Claus Offe, Martin Endreß, and two anonymous reviewers. All mistakes and omissions are of course my own.

\section{References}

Alexander, J. C. (1984). Three models of culture and society relations: Towards an analysis of Watergate. Sociological Theory, 3, 290-314.

Alexander, J. C. (1988). Culture and political crisis: "Watergate" and Durkheimian sociology. In J. C. Alexander (Ed.), Durkheimian sociology: Cultural studies (pp. 187-224). Cambridge: Cambridge University Press.

Alexander, J. C. (1995). Watergate. In S. M. Lipset (Ed.), The encyclopaedia of democracy (Vol. 1, pp. 1367-1369). London: Routledge.

\footnotetext{
${ }_{28}$ Here processes of mediation and self-regulation are addressed (see Arnold and Kay 1995).
} 
Arnold, B. L., \& Kay, F. M. (1995). Social capital, violations of trust and the vulnerability of isolates: The social organization of law practice and professional self-regulation. International Journal of the Sociology of Law, 23(4), 321-346.

Arnott, D. C. (2007). Research on trust: A bibliography and brief bibliometric analysis of the special issue submissions. European Journal of Marketing, 41, 1203-1240.

Ashby, R. W. (1968). Principles of the self-organizing system. In W. Buckley (Ed.), Modern systems research for the behavioral scientist: A sourcebook (pp. 108-128). Chicago: Aldine Publishing.

Bacharach, M., \& Gambetta, D. (2001). Trust in signs. In K. S. Cook (Ed.), Trust in society (pp. 148-184). New York: Russell Sage Foundation.

Bachmann, R., \& Lane, C. (Eds.). (1998). Trust within and between organizations. Conceptual issues and empirical applications. Oxford: Oxford University Press.

Bachmann, R., \& Zaheer, A. K. S. (Eds.). (2006). The handbook of trust research. Cheltenham: Edward Elgar.

Bachmann, R., \& Zaheer, A. K. S. (Eds.). (2008). Landmarks papers on trust (Vol. 2). Cheltenham: Edward Elgar.

Basse, M. (1993). Certitudo spei. Thomas von Aquins Begründung der Hoffnungsgewißheit und ihre Rezeption bis zum Konzil von Trient als ein Beitrag zur Verhältnisbestimmung von Eschatologie und Rechtfertigungslehre. Göttingen: Vandenhoeck \& Ruprecht.

Berger, A. (1953). Encyclopaedic dictionary of Roman law. Transactions of the American Philosophical Society New Series, 43(2), 333-808.

Borowik, I. (2002). The Roman Catholic Church in the process of democratic transformation: The case of Poland. Social Compass, 49(2), 239-252.

Bradford, K. D., Michael Crant, J., \& Phillips, J. M. (2009). How suppliers affect trust with their customers: The role of salesperson job satisfaction and perceived customer importance. Journal of Marketing Theory and Practice, 17, 383-394.

Burgess, J. P. (1997). The East German church and the end of communism. New York, Oxford: Oxford University Press.

Callies, H. (1989). Zum römischen Klientelsystem, zumal in den politischen Auseinandersetzungen der späten Republik. In H. H. Nolte (Ed.), Patronage und Klientel: Ergebnisse einer polnisch-deutschen Konferenz (pp. 26-34). Köln, Wien: Böhlau.

Chua, R. Y. J., Ingram, P., \& Morris, M. (2008). From the head and the heart: Locating cognition- and affect-based trust in managers' professional networks. Academy of Management Journal, 51, 436-452.

Citrin, J., \& Green, D. P. (1986). Presidential leadership and the resurgence of trust in government. British Journal of Political Science, 16(4), 431-453.

Cordell, K. (1990). The role of the evangelical church in the GDR. Government and Opposition, 25(1), 48-59.

Dayan, D., \& Katz, E. (1992). Media events: The live broadcasting of history. Cambridge: Harvard University Press.

de Vries, P., Midden, C., \& Bouwhuis, D. (2003). The effects of errors on system trust, self-confidence, and the allocation of control in route planning. International Journal of Human-Computer Studies, 58(6), 719-735.

Desportes, Y. (2006). Trust, confidence and reliance: Reflections of a linguist. Global Economy Journal, $6(1), 1-15$.

Dunn, J. (1984). The concept of 'trust' in the politics of John Locke. In R. Rorty, J. B. Schneewind, \& Q. Skinner (Eds.), Philosophy in history. Essays on the historiography of philosophy (pp. 279-301). Cambridge: Cambridge University Press.

Earle, T. C. (2009). Trust, confidence, and the 2008 global financial crisis. Risk Analysis, 29, 785-792.

Ebert, T. A. E. (2007). Interdisciplinary trust meta-analysis: Analysis of high rank trust articles between 1966 and 2006, discussion paper 2007-18. Munich: LMU: Munich School of Management.

Endreß, M. (2010). Vertrauenskrisen und Vertrauensverluste, Widerspruch. Münchner Zeitschrift für Philosophie, 51, 27-40.

Engels, L. J. (1964). Fiducia dans la vulgate le problème de traduction Parrhesia-fiducia. Graecitas et latinitas christianorum primaera, Supplementa I, 99-141.

Engels, L. J. (1969). Fiducia. In T. Klauser, et al. (Eds.), Reallexikon für Antike und Christentum. Sachwörterbuch zur Auseinandersetzung des Christentums mit der Antiken Welt (Vol. VII, pp. 839-877). Stuttgart: Hiersemann, Anton. 
Fehir, F., \& Arato, A. (Eds.). (1991). Crisis and reform in Eastern Europe. New Brunswick: Transaction Publishers.

Flores, F., \& Solomon, R. C. (1998). Creating trust. Business Ethics Quarterly, 8(2), 205-232.

Fraenkel, E. (1916). Zur Geschichte des Wortes fides. Rheinisches Museum für Philologie, 71, 187-199.

Francis, C. B. (1989). The progress of protest in China: The spring of 1989. Asian Survey, 29(9), 898-915.

Freyburger, G. (1986). Fides. Étude sémantique et religieuse depuis les origines jusqu'à l'époque augustéenne. Paris: Les Belles Lettres.

Fuchs, P. (1997). Adressabilität als Grundbegriff der soziologischen Systemtheorie. Soziale Systeme, 1(3), 57-79.

Gambetta, D. (1988a). Can we trust trust? In D. Gambetta (Ed.), Trust: Making and breaking cooperative relations (pp. 213-237). New York, Oxford: Basil Blackwell.

Gambetta, D. (1988b). Foreword. In D. Gambetta (Ed.), Trust: Making and breaking cooperative relations. New York, Oxford: Basil Blackwell.

Gauthier, R. A. (1951). Magnanimité: L'idéal de la grandeur dans la philosophie païenne et dans la théologie chrétienne, (Bibliothèque thomiste 28). Paris: J. Vrin.

Giddens, A. (1990). The consequences of modernity. Stanford: Stanford University Press.

Göppert, H. (1892). 'Zur fiducia cum amico contracta,' Zeitschrift der Savigny-Stiftung für Rechtsgeschichte. Romanistische Abteilung, 13, 317-356.

Granovetter, M. S. (1973). The strength of weak ties. American Journal of Sociology, 78(6), 1360-1380.

Greenidge, A. H. J. (1977). Infamia: Its place in Roman public and private law. Darmstadt: Scientia Verlag Aalen.

Gruen, E. S. (1982). Greek pistis and Roman fides. Athenaeum: studi periodici di letteratura e storia dell'antichità, 60, 50-68.

Gu, E. X. (1998). 'Non-establishment' intellectuals, public space, and the creation of non-governmental organizations in China: The Chen Ziming-Wang Juntao Saga. The China Journal, 39, 39-58.

Guiot, J. M. (1977). Attribution and identity construction: Some comments. American Sociological Review, 42(5), 692-704.

Hardin, R. (2002). Trust and trustworthiness. New York: Russell Sage Foundation.

Heck, P. (1889). Die fiducia cum amico contracta, ein Pfandgeschäft mit Salman. Zeitschrift der SavignyStiftung für Rechtsgeschichte. Romanistische Abteilung, 10, 82-138.

Heinze, R. (1972). Fides. In R. Heinze (Ed.), (published by Erich Burck) Vom Geist des Römertums. Ausgewählte Aufsätze (pp. 59-81), 4th Edn. Darmstadt: Teubner.

Hirschman, A. O. (1993). Exit, voice, and the fate of german democratic republic. World Politics, 45(1), 173-202.

Hobbes, T. (1994). The elements of law natural and politics. Oxford, New York: Oxford University Press.

Hölkeskamp, K. J. (2000). Fides-Deditio in fidere-Dextra data et accepta: Recht, Religion und Ritual in Rom. In C. Brunn (Ed.), The Roman middle republic. Politics, religion and historiography. 400-133 BC (Papers from Conference at the Institutum Romanum Finlandiae, September 11-12, 1998) (pp. 223-250). Rome: Institutum Romanum Finlandiae.

Holton, R. (1994). Deciding to trust, coming to believe. Australasian Journal of Philosophy, 72(1), 63-76.

Horváth, A., \& Szakolczai, Á. (1992). The dissolution of communist power: The case of Hungary. London, New York: Routledge.

Hough, J. F. (1997). Democratization and revolution in the USSR, 1985-1991. Washington: The Brookings Institution.

Hunzinger, A. W. (1906). Das Furchtproblem in der katholischen Lehre von Augustin bis Luther. Leipzig: Deichert.

Jaeger, H., \& Eughien, S. J. (1957). Parrhesia et fiducia. Étude spirituelle des mots. Studia Patristica, 1, 221-239.

Jarvenpaa, S. L., Tractinsky, N., \& Vitale, M. (2002). Consumer trust in an internet store. Information Technology and Management, 1, 45-71.

Jones, E. E., \& Harris, V. A. (1967). The attribution of attitudes. Journal of Experimental Social Psychology, 3, 1-24.

Jones, E. E., et al. (Eds.). (1971). Attribution: Perceiving the causes of behavior Morristown. New Jersey: General Learning Press.

Kaser, M. (1956). Infamia und ignominia in den römischen Rechtsquellen, Zeitschrift der SavignyStiftung für Rechtsgeschichte. Romanistische Abteilung, 73, 220-278. 
Klandermans, B. (1987). Potentials, networks, motivations, and barriers: Steps towards participation in social movements. American Sociological Review, 52(4), 519-531.

Kochanowicz, J. (2004). Trust, confidence, and social capital in Poland: A historical perspective. Proceedings of the British Academy, 123, 63-83.

Lang, G. E., \& Lang, K. (1980). Polling on Watergate: The battle for public opinion. The Public Opinion Quarterly, 44(4), 530-547.

Lang, G. E., \& Lang, K. (1983). The battle for public opinion. The president, the press, and the polls during Watergate. New York: Columbia University Press.

Larson, D. W. (2004). Distrust: Prudent, if not always wise. In R. Hardin (Ed.), Distrust (pp. 34-59). New York: Russell Sage Foundation.

Lee, M. K. O., \& Turban, E. (2001). A trust model for consumer internet shopping. International Journal of Electronic Commerce, 6(1), 75-91.

Levi, M. (2000). Political trust and trustworthiness. Annual Review of Political Science, 3, 475-507.

Lewis, J. D., \& Weigert, A. J. (2005). Social atomism, holism, and trust. Sociological Quarterly, 26(4), $455-471$.

Li, L. (2004). Political trust in rural China. Modern China, 30(2), 228-258.

Lipset, S. M., \& Schneider, W. (1983). The decline of confidence in American institutions. Political Science Quarterly, 98(3), 379-402.

Ljunggren, G. (1921). Zur Geschichte der christlichen Heilsgewissheit, von Augustin bis zur Hochscholastik, (PhD-dissertation) Göttingen.

Locke, J. (1954). Essays in the law of nature. Oxford: Clarendon Press.

Locke, J. (2002). Two treatises of government. Cambridge: Cambridge University Press.

Luhmann, N. (1979). Trust and power. Chichester: Wiley.

Luhmann, N. (1988). Familiarity, confidence and trust: Problems and alternatives. In D. Gambetta (Ed.), Trust: Making and breaking cooperative relations (pp. 94-107). Oxford: Basil Blackwell.

Maier, C. S. (1997). Dissolution: The crisis of communism and the end of East Germany. Princeton: University of Princeton Press.

Marková, I. (2004). Introduction: Trust/risk and trust/fear. Proceedings of the British Academy, 123, $1-23$.

Mayntz, R. (1988). Soziale Diskontinuitäten: Erscheinungsformen und Ursachen. In K. Hierholzer \& H. G. Wittmann (Eds.), Phasensprünge und Stetigkeit in der natürlichen und kulturellen Welt (pp. 15-37). Stuttgart: Wissenschaftliche Verlagsgesellschaft.

McLeod, J. M., Brown, J. D., \& Becker, L. B. (1977). Watergate and the 1974 congressional elections. The Public Opinion Quarterly, 41(2), 181-195.

Miller, A. H. (1974). Political issues and trust in government: 1964-1970. The American Political Science Review, 68(3), 951-972.

Miller, A. H., Goldenberg, E. N., \& Erbring, L. (1979). Type-set politics: impact of newspapers on public confidence. The American Political Science Review, 73(1), 67-84.

Mishler, W., \& Rose, R. (1997). Trust, distrust and scepticism: Popular evaluations of civil and political institutions in post-communist societies. The Journal of Politics, 59(2), 418-451.

Mishler, W., \& Rose, R. (2005). What are the political consequences of trust? A test of cultural and institutional theories in Russia. Comparative Political Studies, 20(10), 1-129.

Mureşan, I. (2006). Trust in political institutions in central and Eastern Europe. The Romanian Journal of Political Sciences, 6(1), 65-84.

Mutti, A. (2000). Particularism and the modernization: Process in southern Italy. International Sociology, 15(4), 579-590.

Newton, K. (2011). Trust, social capital, civil society, and democracy. International Political Science Review, 22, 201-214.

Newton, K. (2012). Taking a bet with ourselves: Can we put trust in trust? WZB Newsletter, 135, 6-8.

Niemeyer, T. H. (1891). 'Fiducia cum amico und depositum,' Zeitschrift der Savigny-Stiftung für Rechtsgeschichte. Romanistische Abteilung, 12, 297-324.

Offe, C. (1999). How can we trust our fellow citizens? In M. E. Warren (Ed.), Democracy and trust (pp. 42-87). Cambridge: Cambridge University Press.

Opp, K. D., \& Gern, C. (1993). Dissident groups, personal networks, and spontaneous cooperation: The East German revolution of 1989. American Sociological Review, 58(5), 659-680.

Parker, G. R., \& Davidson, R. H. (1979). Why do Americans love their congressmen so much more than their congress? Legislative Studies Quarterly, 4(1), 53-61.

Parsons, T. (1969). Political and social structure. New York, London: Free Press. 
Pfaff, S. (1996). Collective identity and informal groups in revolutionary mobilization: East Germany in 1989. Social Forces, 75(1), 91-118.

Plato. (2000). The republic. Cambridge: Cambridge University Press.

Pollack, D. (2002). The change in religion and church in eastern Germany after 1989: A research note. Sociology of Religion, 63(3), 373-387.

Putnam, R. D. (1992). Making democracy work: Civic traditions in modern Italy. Princeton, New Jersey: Princeton University Press.

Rehman, S. U., et al. (2005). What to wear today? Effect of doctor's attire on the trust and confidence of patients. The American Journal of Medicine, 118, 1279-1286.

Sapsford, R., \& Abbott, P. (2006). Trust, confidence and social environment in post-communist societies. Communist and Post-Communist Studies, 39, 59-71.

Schudson, M. (1993). Watergate in American memory how we remember, forget, and reconstruct the past. New York: Basic Books.

Seidl, E. (1952). PISTIS: In der griechischen Literatur bis zur Zeit des Peripatos, (PhD-dissertation) Innsbruck.

Seligman, A. B., \& Füzer, K. (1994). The problem of trust and the transition from state socialism. Comparative Social Research, 14, 193-221.

Semmes, C. E. (1991). Developing trust: Patient-practitioner encounters in natural health care. Journal of Contemporary Ethnography, 19(4), 450-470.

Simmel, G. (2004). The philosophy of money. London: Taylor \& Francis.

Smith, C. (2005). Understanding trust and confidence: Two paradigms and their significance for health and social care. Journal of Applied Philosophy, 22, 299-316.

Staritz, D. (1991). The relationship of socio-structural development and political culture in the GDR. In M. Gerber (Ed.), Studies in GDR culture and society (pp. 65-73). Washington: University Press of America.

Suh, B., \& Han, I. (2002). Effect of trust on customer acceptance of Internet banking. Electronic Commerce Research and Applications, 1, 247-263.

Sztompka, P. (1996a). Trust in emerging democracy. Lessons from Poland. International Sociology Journal, 11(1), 37-63.

Sztompka, P. (1996b). Looking back: The year 1989 as a cultural and civilizational break. Communist and Post-Communist Studies, 29(2), 115-129.

Sztompka, P. (1998). Trust, distrust and the paradox of democracy. European Journal of Social Theory, $1(1), 19-32$.

Thomas, J. G. (2001). Pistis und Wissen. Zur Frage nach der Gewißheit im stoischen Erkenntnisprozeß. Archiv für Begriffsgeschichte, 42, 105-137.

Thomas, A. (2006). Summa theologiae: Courage. In A. Ross \& P. G. Walsh (Eds.), vol. 42. Cambridge: Cambridge University Press.

Tonkiss, F. (2009). Trust, confidence and economic crisis. Intereconomics, 44(4), 196-202.

Unverhau, D. (Ed.). (1999). Lustration, Akteneröffnung, demokratischer Umbruch in Polen, Tschechien, der Slowakei und Ungarn. Hannover: LIT-Verlag.

Uslaner, E. M. (2002). The moral foundations of trust. New York: Cambridge University Press.

Uslaner, E. M. (2008). Trust as a moral value. In D. Castiglione, J. W. van Deth, \& G. Wolleb (Eds.), Handbook of social capital (pp. 101-121). Oxford: Oxford University Press.

Wallace-Hadrill, A. (1989). Patronage in Roman society: From republic to empire. In A. Wallace-Hadrill (Ed.), Patronage in ancient society (pp. 63-87). London, New York: Routledge.

Warf, B. (2011). Myths, realities, and lessons of the Arab spring. The Arab World Geographer, 14(2), $166-168$.

Weatherford, M. S. (1984). Economic 'stagflation' and public support for the political system. British Journal of Political Science, 14(2), 187-205.

Weber, M. (2001). The protestant ethic and the spirit of capitalism. London: Taylor \& Francis Ltd.

Zimmer, T. A. (1979). The impact of Watergate on the public's trust in people and confidence in the mass media. Social Science Quarterly, 58(4), 743-752. 